\title{
The prospective science teachers' perspectives of dissection experiments: Calf's heart, fish and frog dissection
}

\author{
Şenol Beşoluk ${ }^{1 \mathrm{a}}$ and Eda Demirhan ${ }^{2}$ \\ ${ }^{1}$ Faculty of Education, Department of Science Education, Sakarya University, Turkey \\ ${ }^{2}$ Faculty of Education, Department of Special Education, Sakarya University, Turkey
}

\begin{abstract}
This study aims to find out the sophomore prospective science teachers' cognitive emotional reactions, physiological-motor reactions with regard to a calf's heart, fish and frog dissection in biology laboratory experiments. Meanwhile to find out if they had a choice, they would prefer to do or not to do these dissections. In this study a phenomenological design was used which is involving a qualitative research method. The sample consisted of totally 43 (37 female and 6 male) sophomore prospective science teachers in 2013-2014 spring term. The data was collected with using of a questionnaire which was developed by one of the researcher. The data was analyzed through qualitative descriptive analysis. According to the results of the study, the prospective science teachers' cognitive emotional reactions were mainly categorized as positive and negative feelings. Positive feelings were curiosity, interest, excitement, enjoyable and pleasure and also negative feelings were disgust, displeasure, sad, stress and fear. Also five physiological-motor reactions were found. These were queasiness, trembling hands, loss of appetite, dizziness and dry mouth.
\end{abstract}

Keywords: Dissection, science education, disgust, heart, fish, frog

\section{Introduction}

Dissection is an essential part of biology and medical education and it has been mentioned as a "controversial pedagogical practice" in the academic literature [19]. Dissection has been using as a tool for learning anatomy and physiology for over two millennia, artists (e.g., Leonardo da Vinci, Michelangelo), scientists (e.g., Aristotle, Galen, and Vesalius) and medical students [12]. After the 1960 Biological Science Curriculum Study there was an increase in the use of dissection in high school classrooms [1]. According to some of the

\footnotetext{
${ }^{a}$ Corresponding author: edemirhan@sakarya.edu.tr
} 
teachers' report dissection is pedagogical, realistic, experiential and ethical procedure. It has been referred as pedagogical because it reinforces classroom content; realistic because it illustrates the complexity and similarities/differences among organisms; experiential because it provides hands-on learning and allows students to develop skills with dexterity and lab procedures; and ethical because it is "an opportunity for students to develop respect and admiration for life [19]. Similarly National Science Teachers Association [17, 18] support using animals in the classroom because it can help students to develop skills of observation and comparison, discover the shared and unique structures and processes of specific organisms, and develop a greater appreciation of the complexity of life. According to Barr and Herzog [6] using dissection is beneficial both for teachers because they feel that it provides a valuable hands-on learning experience and for students because of leading "exciting" educational experience in classroom. Although dissection can provide much vulnerable advantage, there are several opposite idea using animals in the classroom. Meanwhile DeRosa [10] asserted that dissection is a waste of animal life. Therefore ethical and environmental concerns considering the killing of animals [23] and ignoring of animal welfare standards [8,15 and 20] are controversially discussed for using dissection in education. Also several researchers asserted that dissection can lead to psychological trauma in students $[10,16]$ and they can be discouraged from their future careers which are related with the fields of medicine and science as a result of doing dissections [6]. Therefore Barr and Herzog [6] supported that dissection tasks should be "an option rather than a requirement" for Biology II students. Because of this in the United States, several states have enacted laws that protect the rights of students who choose not to dissect at the present time (Physicians Committee for Responsible Medicine [24].

Dissection has an impact on students' emotions. Pekrun, Götz, Frenzel, Barchfeld and Perry [21] defined emotions as an involving set of interrelated psychological processes and mainly can be categorized as negative emotions (e.g., anger, sadness) or positive emotions (e.g., relief, hope). And emotions have an effect on students' cognitive processes and performance [22]. In dissection tasks students can feel many different emotions such as disgust, anxiety, curiosity and so on at the same times. Demirhan [9] showed that $75 \%$ of the prospective science teachers preferred to do dissection even if it has alternatives and although dissection causes several negative emotions such as disgust, sad and fear. Emotion of anxiety and also disgust is more mentioned about studies of dissection. Randler, Hummel and Wüst-Ackermann [25] showed up that the preservice science teachers felt high disgust in fish dissection task. One another study related with dissection of fish was showed up that low disgust and low anxiety were positively predicted by interest and competence and also high disgust and anxiety can lead to high tension [26].

Holstermen et al. [13] found that 7th to 10th grade students' interest was negatively related to feelings of disgust prior to and during the dissection while feelings of disgust at the beginning of the class negatively predicted students' interest during the dissection. Also Holstermann, Grube and Bögeholz [14] found that disgusted students saw themselves as less effective and reported lower interest in the heart than students who did not feel that emotion during dissection of pig's heart. Meanwhile Fančovičová, Prokop and Lešková [11] supported those prior experiences with dissection tasks correlates with positive attitudes toward dissections. Research on science teachers' perspectives reveals that as many as $75-79 \%$ of biology teachers use dissection in their classrooms, and, when asked, report both benefits and concerns associated with the practice [19].

So in this paper we aimed to find out prospective science teachers' cognitive emotional reactions, physiological-motor reactions and in brief perceptions about the experience of a calf's heart, fish and frog dissection in a qualitative way. Meanwhile to show up the prospective science teachers' responses whether or not they would choose to do these dissection tasks if they had a choice. 


\section{Method}

For our purposes, qualitative methodology was used to (1) provide subjective perceptions of prospective science teachers (2) explore if they had a chance, whether they chose to dissect or not.

\subsection{Participants}

The participants of the terms 2013/14 were prospective science teachers. Fourty-three sophomore prospective science teachers dissected a calf's heart, fish and frog during their biology classes. A total $86.1 \%$ were female, and $13.9 \%$ male, and their participation in the study was voluntary and anonymous. The mean age of the respondents was 20.3 years (range between 19 and 22). In the results of the study, participants were labeled, for example in the label $F_{13}, F$ indicates gender (Female) and 13 indicates participants row (thirteenth student of the study). Also HD refers to heart dissection, FD refers to fish dissection and FGD refers to frog dissection.

\subsection{Procedure}

Data collection took place in spring term of the 2013-2014 academic year. All participants were enrolled for the first time in heart, fish and frog dissections and all dissection tasks were performed in groups of four or three. Each dissection sessions was supervised by researchers. Immediately after the participants had carried out the dissections in laboratory, the questionnaire which had been developed by one of the researcher [9] was applied. It contained a check-list of sensations and reactions that the students experienced during the dissection sessions and formed of three open-ended questions: (1) what cognitive emotional reactions did you experience while handling of a calf's heart/ fish / frog? Why? Please explain by giving examples. (2) What physiological-motor reactions did you experience during your handling of a calf's heart/ fish / frog? Why? Please explain by giving examples. (c) If you had a choice, would have rather not done these dissections? Why?

At first their answers were grouped according to check-list. Then their statements which were gathered from open-ended part of the questionnaire were used to exemplify by direct quotations.

\section{Findings}

In this section findings were presented as related with our research questions relatively for each dissection session. First of all prospective science teachers' cognitive emotional reactions, then physiological and motor reactions were analyzed. After then their opinions were analyzed that if they had a choice to do or not to do these dissections, they would chose to do them.

The prospective science teachers' cognitive emotional reactions were mainly categorized as positive and negative feelings. Positive feelings were curiosity, interest, excitement, enjoyable and pleasure and also negative feelings were disgust, displeasure, sad, stress and fear in Table 1. 
Table 1. Prospective science teachers' cognitive emotional reactions in dissection sessions.

\begin{tabular}{|c|c|c|c|c|c|c|c|}
\hline \multirow{2}{*}{\multicolumn{2}{|c|}{$\begin{array}{l}\text { Cognitive emotional } \\
\text { reactions }\end{array}$}} & \multicolumn{2}{|c|}{ Heart } & \multicolumn{2}{|c|}{ Fish } & \multicolumn{2}{|c|}{ Frog } \\
\hline & & & & & & & \\
\hline \multirow{5}{*}{$\begin{array}{l}\text { Positive } \\
\text { feelings }\end{array}$} & Curiosity & 35 & 4 & 30 & 3 & 28 & 4 \\
\hline & Interest & 30 & 4 & 23 & 3 & 22 & 4 \\
\hline & Excitement & 18 & 1 & 14 & 1 & 19 & 3 \\
\hline & Enjoyable & 16 & 2 & 9 & 1 & 6 & 0 \\
\hline & Pleasure & 14 & 1 & 4 & 0 & 5 & 0 \\
\hline \multirow{5}{*}{$\begin{array}{l}\text { Negative } \\
\text { feelings }\end{array}$} & Disgust & 4 & 1 & 12 & 2 & 20 & 3 \\
\hline & Displeasure & 6 & 1 & 8 & 4 & 12 & 3 \\
\hline & Sad & 0 & 0 & 0 & 0 & 12 & 0 \\
\hline & Stress & 1 & 0 & 6 & 1 & 9 & 1 \\
\hline & Fear & 0 & 0 & 0 & 0 & 6 & 1 \\
\hline
\end{tabular}

According to Table 1, female prospective science teachers were marked the most positive feelings as curiosity then respectively interest, excitement, enjoyable and pleasure for all dissection sessions. Although disgust was the most mentioned negative feeling for fish and frog dissection, displeasure was the most mentioned for heart dissection session for female. Male prospective science teachers were mainly marked curiosity and interest as positive feelings and according to negative feelings domain disgust and displeasure were. In generally without noticing participants' gender, prospective science teachers were more mentioned positive feelings for all dissection sessions. At the same time participants were usually mentioned negative feelings for frog dissection. Several prospective science teachers' quotations were indicated below.

$\mathrm{M}_{4}$ : To see a heart while it was beating was really exciting for me (FGD)

$\mathrm{F}_{6}$ : I've never done like this thing cutting activities and this makes me curious

(HD)

$\mathrm{F}_{15}$ : 10 minutes before it was alive, I saw it, but then we killed it. This is

really sad event (FGD)

$\mathrm{F}_{8}$ : The smell of the fish was terrible. I felt disgust (FD)

The participants indicated five physiological-motor reactions. These were queasiness, trembling hands, loss of appetite, dizziness and dry mouth that can be seen in Table 2 .

Table 2. Prospective science teachers' physiological and motor reactions in dissection sessions.

\begin{tabular}{|c|c|c|c|c|c|c|}
\hline \multirow{2}{*}{$\begin{array}{l}\text { Physiological- } \\
\text { motor reactions }\end{array}$} & \multicolumn{2}{|c|}{ Heart } & \multicolumn{2}{|c|}{ Fish } & \multicolumn{2}{|c|}{ Frog } \\
\hline & Female (f) & Male (f) & Female (f) & Male (f) & Female (f) & Male (f) \\
\hline Queasiness & 11 & 2 & 21 & 4 & 21 & 4 \\
\hline Trembling hands & 2 & 0 & 1 & 0 & 3 & 0 \\
\hline Loss of appetite & 1 & 0 & 7 & 0 & 3 & 0 \\
\hline Dizziness & 0 & 0 & 1 & 0 & 5 & 0 \\
\hline Dry mouth & 0 & 0 & 1 & 0 & 3 & 0 \\
\hline
\end{tabular}

According to Table 2, without noticing participants' gender the most marked physiological and motor reaction was queasiness for all dissection sessions. One of the important results that male participants were just mentioned about queasiness not the other physiological and motor reactions. In heart dissection female participants were marked mainly queasiness then trembling hands and loss of appetite. In fish dissection they were mainly mentioned about queasiness after then loss of appetite and then the others. In frog dissection they were mainly mentioned about queasiness then dizziness after then the others. Several prospective science teachers' quotations were indicated below.

$F_{23}$ : When I see blood, I always feel queasiness (HD) 
$M_{1}:$ I'm generally responsible for cooking fish at home so I spare fish's

organs. But in here to research each organ uhh, it was ugly (FD)

$F_{2}$ : Because of its smell, I gave up to eat lunch (FD)

$F_{16}$ : My hands were trembling in the lesson because of my fear of frog (FGD) Table 3 .

The participants' choices about to doing dissection sessions or not were shown in

Table 3. Responses about whether or not they would choose to do the dissections if they had a choice

\begin{tabular}{|c|c|c|c|c|c|c|}
\hline & \multicolumn{2}{|c|}{ Heart } & \multicolumn{2}{|c|}{ Fish } & \multicolumn{2}{|c|}{ Frog } \\
\hline & Female (f) & Male (f) & Female (f) & Male (f) & Female (f) & Male (f) \\
\hline Yes & 34 & 3 & 26 & 3 & 23 & 4 \\
\hline No & 3 & 3 & 11 & 3 & 14 & 2 \\
\hline
\end{tabular}

In Table 3, prospective science teachers' positive responses in other words "yes" were gradually fall down from heart to frog dissections. But in generally positive responses were more than negative responses. Several prospective science teachers' quotations were indicated below.

$\mathrm{F}_{31}$ : Although I felt disgust sometimes, I prefer to do this experiment because

I think it was instructive

$\mathrm{F}_{18}$ : I touch all organs of it, I think it's important may be I don't have a

change again to do this experiment (FD)

$\mathrm{F}_{22}$ : No, because I loathe frogs (FGD)

To sum up, although some of the prospective science teachers would have preferred not to do this experiment, the majority were not of that opinion.

\section{Discussion and conclusion}

In this study prospective science teachers' cognitive emotional and physiological-motor reactions were investigated in different dissection sessions. Then their opinions were analyzed that if they had a choice to do or not to do these dissections, they would chose to do them. According to result of study prospective science teachers' cognitive emotional reactions were mainly categorized as positive (curiosity, interest, excitement, enjoyable and pleasure) and negative feelings (disgust, displeasure, sad, stress, fear). Although they talked about some negative feelings, they were mainly mentioned about positive feelings without noticing dissection sessions. And there are several researches which support this result $[2,5$ and 9]. Meanwhile the effects of negative feelings don't rule out. For example disgust is much more important in dissection sessions. Also according to some of researchers it was the most influential emotional reaction [3, 4]. Likewise Randler et al. [25] investigated their students' reactions for disgust ratings immediately after the respective lessons and according to result of their study, the dissection of a fish elicited high disgust responses. Holstermann et al. [13] showed that interest was negatively related to disgust prior to and during the dissection of a pig's heart. Holstermann et al. [14] found that participants who felt more disgust were less effective during the dissection. All aforementioned studies showed one more time that emotions are more important in educational settings.

Also the prospective science teachers' physiological-motor reactions were found as queasiness, trembling hands, loss of appetite, dizziness and dry mouth. And the most marked physiological and motor reaction was queasiness for all dissection sessions. According to prospective science teachers' quotations this may because of mainly smell and blood.

Last result of this study that although some of the prospective science teachers would have preferred not to do this experiment, the majority were not of that opinion. According 
to this result and prospective science teachers' quotations we can claim that these dissection sessions can use in biology lessons to make lessens more attractive.

\section{References}

1. American Antivivisection Society. Dying to learn: animal use in education, history of vivisection and dissection., (2012). www.dyingtolearn.org/animalUseHistory.html

2. Arora, L., \& Sharma, B.R. Assessment of role of dissection in anatomy teaching from the perspective of undergraduate Students: A qualitative study. Ibnosina Journal of Medicine and Biomedical Sciences, 59-65., (2011).

3. Bögeholz, S., \& Rüter, S. Wenn Erfahrung weh tut [The dark side of nature experience]. In: Lehren fürs Leben, eds. Gropengießer H, Janßen-Bartels A and Sander E pp 80-95. Köln, Germany: Aulis Verlag Deubner., (2004).

4. Maloney, R. Exploring virtual fetal pig dissection as a learning tool for female high school biology students. Educational Research and Evaluation, 11(6), 591- 603., (2005).

5. Arráez-Aybar, L.A., Castaño-Collado, G., \& Casado-Morales, I. A study of cognitiveaffective and physiological-motor reactions to human dissection in Spanish students of human anatomy. European Journal of Anatomy, 11(S1), 67-71., (2014).

6. Barr, G., \& Herzog, H. (2000). Fetal pig: The high school dissection experience. Society \& Animals, 8(1), 53-69. Hart, L. A., Wood, M. W., \& Hart, B. L. Why dissection? Animal use in education. Westport, CT: Greenwood Press., (2008).

7. Bernstein, P. L. Dissection as inquiry: Using the "peanut observation" activity to promote a revised paradigm of dissection and facilitate student involvement and understanding. American Biology Teacher, 62(5), 374-77., (2000).

8. Bishop, L. J., \& Nolen, A. L. Animals in research and education: Ethical issues. Kennedy Institute of Ethics Journal, 11(1), 91-112., (2001).

9. Demirhan, E. Miracle or Cruelty? The Sophomore Prospective Science Teachers' Perspective of Chicken Embryonic Development. Procedia-Social and Behavioral Sciences, 152, 575-581., (2014). http://dx.doi.org/10.1016/j.sbspro.2014.09.246.

10. DeRosa, B. Is dissection necessary? Children and Animals, 10(3), 1-2., (1986).

11. Fančovičová, J., Prokop, P., \& Lešková, A. Perceived disgust and personal experiences are associated with acceptance of dissections in schools. Eurasia Journal of Mathematics, Science and Technology Education, 9(3), 311-318., (2013). http://dx.doi.org/10.12973/eurasia.2013.938a.

12. Hart, L. A., Wood, M. W., \& Hart, B. L. Why dissection? Animal use in education. Westport, CT: Greenwood Press., (2008).

13. Holstermann, N., Ainley, M., Grube, D., Roick, T., \& Bögeholz, S. The specific relationship between disgust and interest: Relevance during biology class dissections and gender differences. Learning and Instruction, 22(3), 185-192., (2012). http://dx.doi.org/10.1016/j.learninstruc.2011.10.005.

14. Holstermann, N., Grube, D., \& Bögeholz, S. The influence of emotion on students' performance in dissection exercises. Journal of Biological Education, 43, 164-168., (2009).

15. Hug, B. Re-examining the practice of dissection: What does it teach? Journal of $\begin{array}{llll}\text { Curriculum } & \text { Studies, } & \text { 40(1), } & \text { (2008). }\end{array}$ http://dx.doi.org/10.1080/00220270701484746.

16. Lieb, M. J. Dissection: A valuable motivational tool or a trauma to the high school students? (Master's Thesis, The Foster G. McGraw School of the National College of Education)., (1985). 
17. National Science Teachers Association [NSTA] Responsible use of live animals and dissection in the science classroom. NSTA Position Statement., (2005)

18. National Science Teachers Association [NSTA] Responsible use of live animals and dissection in the science classroom. NSTA position statement., (2008).

19. Oakley J. Science teachers and the dissection debate: Perspectives on animal dissection and alternatives. International Journal of Environmental \& Science Education, 7(2), 253-267., (2012).

20. Oakley, J. Under the knife: Animal dissection as a contested school science activity. Journal for Activist Science and Technology Education, 1(2), 59-67., (2009).

21. Pekrun, R., Götz, T., Frenzel, A. C., Barchfeld, P., \& Perry, R. P. Measuring emotions in students' learning and performance: The Achievement Emotions Questionnaire (AEQ). Contemporary Educational Psychology, 36(1), 36-48., (2011). http://dx.doi.org/10.1016/j.cedpsych.2010.10.002.

22. Pekrun, R., Götz, T., Titz, W., \& Perry, R. P. Academic emotions in students' selfregulated learning and achievement: A program of qualitative and quantitative research., (2002).

23. PETA. How animals are collected and killed for dissection and the alternatives you can choose, The PETA Guide to Animals and the Dissection Industry. People for the Ethical Treatment of Animals, Norfolk, VA., (2004).

24. Physicians Committee for Responsible Medicine. Dissection Alternatives. Retrieved November 21, 2013, (2013) from http://pcrm.org/research/edtraining/dissectionalt

25. Randler, C., Hummel, E., \& Wüst-Ackermann, P. The influence of perceived disgust on students' motivation and achievement. International Journal of Science Education, 35(17), 2839-2856., (2013). http://dx.doi.org/10.1080/09500693.2012.654518.

26. Randler, C., Wüst-Ackermann, P., Vollmer, C., \& Hummel, E. The relationship between disgust, state-anxiety and motivation during a dissection task. Learning and Individual Differences, 22(3), 419-424., (2012). http://dx.doi.org/10.1016/j.lindif.2012.01.005. 